\title{
THE IMPACT OF FOREIGN DIRECT INVESTMENT ON CURRENT ACCOUNT BALANCE: EMPIRICAL EVIDENCE FROM DEVELOPING ASIAN ECONOMIES
}

\author{
Mahnaz Muhammad Ali \\ Assistant Professor, Department of Economics, \\ The Islamia University of Bahawalpur, Pakistan \\ mahnaz.ali@iub.edu.pk \\ Zulaikha Bibi \\ Independent Researcher \\ Rozina Sadiq \\ University of Home Economics Lahore, Pakistan
}

\begin{abstract}
Foreign Direct Investment is considered as a desirable source of capital inflows for developing economies. Developing Asia has become the world's largest host for FDI and received about half of the global FDI inflows (WIR, 2021). Most of the vacant literature on FDI has highlighted its positive contribution towards host economy, however the present study identified the negative bearing of inward FDI on current account balance of the host economy. The present study has used the date for developing Asia from 1980 to 2020 on the study variables and ARDL approach to cointegration is employed to identify the long run relationship between study variables. The data is obtained from the database of United Nations Conference on Trade and Development (UNCTAD). Current account deficit is taken as dependent variable. For explanatory variables, log form of inward FDI, log of GDP and log of Trade Openness (TO) are used. Based on the empirical investigation it is concluded that inward FDI can increase the current account deficit of FDI host economies. As policy suggestion it can be suggested that for developing Asia inward FDI should be sector specific that can upsurge the exports of the country instead increasing the imports of the recipient economy.
\end{abstract}

Key Words: FDI, Current Account Balance, Developing Asia, ARDL.

JEL Classification Codes: F21, F32, C23

\section{INTRODUCTION}

Impact of FDI on Macro Economy

When a corporation, individual or a firm from one country invests in a host country through selfowned business, joint venture or acquires a local firm it is called foreign direct investment (FDI) Moran (2011). Earlier foreign direct investment was discussed on the same basis as trade theories. Separate conception for foreign direct investment started later when World War II ended and global foreign direct investment increased rapidly between different countries. Initially the flow of foreign direct investment was from rich to poor countries. The developed countries were the ones who were investing in the developing countries. One big reason for the direction of the flow of FDI was the unexplored natural resources which were present in the poor countries specially the oil reserves and the low-cost labor force. In the resent years outward foreign direct investment between developing countries is gaining attention. According to global investment competitive report the outward foreign direct investment from developing countries rose to one fifth of world's total foreign direct investment in 2015, which was only $4 \%$ back in 1995. In developing Asia China is the biggest contributor of the foreign direct investment to the neighboring and other developing countries ${ }^{1}$.

Wide range of literature shows bearings of FDI on recipient countries, through different variables (channels). Most prominent effect of FDI on economic development and growth is found in various studied across the old and new literature. FDI can be treated exogenously (Sala-I-Martin, 1996) or endogenously (Romer, 1986) in growth models. Though the studies on impact of FDI on

\footnotetext{
${ }^{1}$ For further details see global investment competitive report 2017/2018.
} 
economic development and Growth show mixed results but mostly positive effect is witnessed (Bengoa \& Robles, 2003; Choe, 2003; Makki \& Somwaro, 2004). Carkovic and Levine (2005) found a weak to neutral effect of FDI on economic growth. There are studies on FDI which are country specific (Irandoust, 2001) and others are based on cross-country statistics (Bengoa \& Robles, 2003) along with the use of time series and cross sectional-data to analyze the influence of FDI on the host countries.

The influence of FDI on recipients is reflected through spillover effects and externalities, which are not clearly declared having positive or negative effects by the set of studies. One possible reason is the nature, type, and source of data. A study conducted by Gorg and Strobl (2001) found positive spillover effect with the use of cross-sectional data and negative effect with the inclusion of time series data. Lipsey (2003) found evidence of positive spillover effect of FDI is not strong, while Kee (2011) stated a strong direct or indirect spillover effect in case of Bangladesh.

\section{Important factors to encourage Inflows of FDI}

Factors which are responsible for the inflows of FDI to the host countries are studied as determinants of foreign direct investment in vast literature on FDI. In a study on eighty developing countries Schneider and Frey (1985) found that FDI is attracted when GNP and real per capita are higher and balance of payment deficit is lower. Taking data on nineteen Sub Saharan African countries BendeNabende (2002) noticed that the size of market, market growth rate, openness of economy, real effective exchange rate, FDI liberalization policy and less restrictive export policies remained the long run determinants of FDI. Same were the findings of Reenu and Sharma (2015) about market size and trade openness to determine FDI inflows. While investigating literature on FDI Ozturk (2007) noticed that stable banking system and financial market regulations were prominent determinants of FDI. In examining the foreign capital inflows Saini and Singhania (2018) learned that per capita income, exchange rate, GDP (growth), commercial interests, domestic inflation, external indebtedness, and trade openness are significant in shaping the inflows of FDI.

\section{Balance of Payment and FDI}

According to Lipsey and Chrystal (2007) the record of countries all transactions with rest of the world in a given time period are recorded in the BoP (balance of payment) account. Current account and capital account are the two main parts of balance of payment. All records related to trade of goods and services are recorded in CA (current account), while KA (capital account) records the flow of loans and investments representing the change in assets and liabilities of a country. In this regard flows of FDI are mentioned in KA which exhibits a direct effect on BoP. The indirect effect of FDI on BoP is through the components of current account balance (imports and exports).

Wide range of early studies on FDI and current account balance has focused on positive effect of FDI as it is considered a safe mode of financial inflows compared to the other short term portfolio investments. It is thought that FDI not only generates necessary funds to finance current account deficit but contributes to spillover effects by the transfer of new technologies and skills to the host country (Markusen \& Venables, 1999; OECD, 2003; Bloomstorm \& Kokko, 2003) ${ }^{2}$. In this context FDI provides a positive impact on current account balance like Ehimare (2011) witnessed positive effect of FDI on current account balance using OLS regression technique for the Nigerien economy.

Developing countries experienced large current account deficits despite being larger recipient of FDI inflows. Existing literature tried to explore the broader aspect of FDI which reveals that the FDI impact on current account can be positive or negative in long run, considering the volume of imports and exports and the profit remittances of the investor nation. If the exports are increased as compared to imports and profits are reinvested in the same country with a healthy competition with the local industry of the similar products, then FDI will positively affect the current account balance. Mensinger (2008) also claimed that impact of FDI proved positive to export promoting countries not small developing countries. Further the study provided a negative relationship between FDI to GDP ratio and FDI to balance of payment ratio for eight transition economies.

\footnotetext{
${ }^{2}$ World bank (1999) also considers FDI as a large source for developing economies finances to upgrade their managerial skills, exports and technology.
} 
In a similar notion considering the fact that FDI is a foreign capital, Kumar (2007) was of the view that FDI could actually be risky for the economies of developing countries as it could not be available in need of financial crises for the host country. The repatriation of profit and withdrawal of investment (capital flight) can damage the economy's asset credibility.

In light of the above discussion FDI impact on current account proves to be multi facet through imports, exports and profit repatriation channels. Taking in consideration the larger imports and the profit eviction ${ }^{3}$ aspects of FDI it can be a cause for widening current account deficit of developing countries despite being larger recipient of FDI. Same fact is discussed in UNCTAD (2002).

According to Jansen (1995) the process of income payments from FDI makes the influence of FDI on current account balance more complicated. With the experience of Brazil and Argentina, Lehman (2002) claimed that the current account deficits in these countries further increased rather decreasing because of the profit extraction by the foreign investors. Woodward (2003) also elaborated the same point of view by taking example of six economies in which FDI caused current account deficit. In the study capital repartition was considered same as the repayment of loan. Seabra and Flach (2005) observed that the FDI inflows worsened the current account balance in long run by enlarging income account deficit due to profit repatriations.

In a study on Pakistan economy Jaffri, Asghar, Ali, and Asjed, (2012) reinforced the same view that the increase of FDI caused an increase in income outflows, resulting long run imbalances in current account balance. In this study Data was taken from 1983 to 2011. ARDL (Autoregressive Distributive Lag) model was used to find out the results. Finding demonstrated that long run significant relationship between foreign direct investment and out flows of income. Error correction term for short run had negative and significant coefficients that confirmed the convergence to long run equilibrium if any disequilibrium occurred in short run.

Similarly, Ali and Shaheen (2013) found the same outcome about Pakistan economy by using ARDL (Autoregressive Distributed Lag) model technique of co-integration. Data for the period 1993Q1- 2011Q4 indicated that FDI inflows are co-integrated with income outflows and empirical findings unveiled the long run relationship between these two variables. Findings of the study also showed a short run positive and statistically significant relationship amongst FDI inflows and income outflows.

FDI can adversely affect the domestic firms if it is involved in the market of already prevailing goods/services with advanced and more sophisticated technology. In this scenario local firms with lack of advanced technologies and skills cannot compete with the foreign investors and this may cause the crowd out of local production of same goods and services. This will leave room for the external firms to reap more profits from the domestic economy causing imbalance in current account of the host country. Apergis, Katrakilidis and Tabakis (2006) analyzed the phenomena of crowding in and crowding out of domestic firms in response to the FDI inflows on a panel of selected countries. The results proved empirical evidence of long run crowding out of local firms, due to loss of the productivity advantage of local products in response to increasing prices of capital goods and decreasing price of domestic products.

Within the different regions of developing Asia studies found that FDI could improve current account balance position of the recipient economies by improving the exports of the recipient economies. Ali, Ahmad and Sadiq (2019) conducted a study taking the panel of East Asian Economies and found that FDI exhibits a negative effect on current account deficit of the recipient economies through enlarging the exports of the host economies. Similarly, another study by Ali and Sadiq (2020) also found that inward FDI can improve the current account balance position of South Asian countries by enhancing the exports of the FDI recipient Economies.

Insight of the literature on the FDI and current account balance reveals that alternative channels have been used for empirical studies to show the association between FDI and current account balance. Studies included different channel of trade balance (Meyer, 2003), imports (Alguacil

\footnotetext{
${ }^{3}$ Mold (2008) considers FDI a very expensive financing if profit remittances are considered as its price for the recipients.
} 
\& Orts 2003"; Ali et al., 2019; Ali \& Sadiq, 2020) exports (Markusen, 1984; Zhang \& Markusen, 19995; Ali et al., 2019; Ali \& Sadiq, 2020) profit remittances (Seabra \& Flach, 2005; Jaffri et al., 2012; Ali \& Shaheen, 2013) and current account deficit itself is taken to analyze the impacts of FDI on host countries. Some empirical work is based on country specific (Seabra \& Flach, 2005; Siddiqui \& Ahmed, 20126; Jaffri et al., 2012; Ali \& Shaheen, 2013) while other studies used panel data (Ali et al. 2019; Ali \& Sadiq, 2020; Apergis et al., 2006; Strauss, 2015; Strauss, 2017) of different countries to evaluate the effect of foreign direct investment on current account balance.

In current scenario of Covid-19 the FDI inflows has fell by 35\% in 2020 due to the lockdown around the world. In spite of the current prevailing situation developing Asia (which is already largest recipient of FDI inflows) is receiving half of the global inflows. Among top 5 FDI host economies four are developing Asian economies (WIR, 2021). Being the largest recipient of FDI inflows, Asian developing countries witness significant effect of FDI on their balance of payment. The effects are not always proved positive on the balance of payment of these countries, as with the inflow of FDI the investors start to increase the imports of primary goods and services and send the profit back to their home countries (Ali \& Shaheen, 2013; Jaffri et al., 2012; Hossain, 2008). In light of the above discussion, it is imperative to investigate the likely impact of inward FDI on current account balance of the developing Asian economies.

The specific objective of the study can be stated as

- To show the share of different regions in total Inflows of FDI.

- To check the impact of FDI inflows on Current Account Deficit of the developing Asian economies.

The hypothesis for the present study can be written as

- Inward FDI has some significant impact on current account deficit of the recipient country.

\section{DATA AND METHODOLOGY}

To test the hypothesis following functional form can be written for study variables.

Current account deficit $=\mathrm{f}$ (FDI inflows, Gross Domestic Product, Trade Openness)

Based on the above given functional form the econometric form of the model can be constructed as follows:

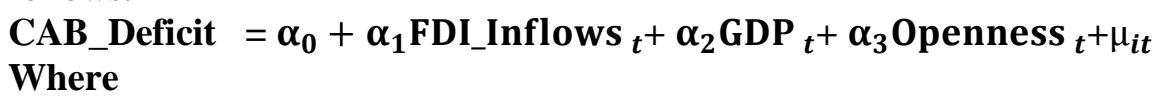

CAB_Deficit: Current Account Balance (excluding workers' remittances measured in million US $\$)^{7}$

FDI_Inflow: Foreign Direct Investment Inflows (measured in million US \$)

GDP: Gross Domestic Product (measured in million US \$)

Openness: Trade Openness measured as (Exports + Imports/ GDP)

Time series data of Developing Asian Economies is used for the empirical analysis and data covered the period from 1980 to 2020. Data is obtained from the database of UNCTAD (United Nations Conference on Trade and Development).

\section{Descriptive Statistics}

Data on FDI inflows is presented in graph 01. Bar chart of data shows FDI inflows to different regions of the world. Data trend clearly demonstrates that developing Asia is the largest recipient region of FDI during last few years therefore it is imperative to explore the potential effect of these inflows on current account balance of the host economy.

\footnotetext{
${ }^{4}$ If demand for intermediary goods and raw material is rising due to FDI it will deteriorate the current account balance.

${ }^{5}$ According to Markusen(1984) type of the investment determines the positive and negative effect of FDI on exports. Increase of horizontal FDI cause a negative impact, while increase in vertical FDI the effect is positive e.g Zhang and Markusen(1999). B.Serap and S. Alylin (2016) used both import and export variables for panel of developing countries and found mixed results of causality between the variables and FDI.

${ }^{6}$ Siddiqui studied the causality of foreign direct investment and current account of Pakistan.

${ }^{7}$ After subtracting worker's remittances from $C A B$ the series become negative indicating deficit of CAB.
} 


\section{Graph 01: Data Trend of FDI Inflows in Different Regions}

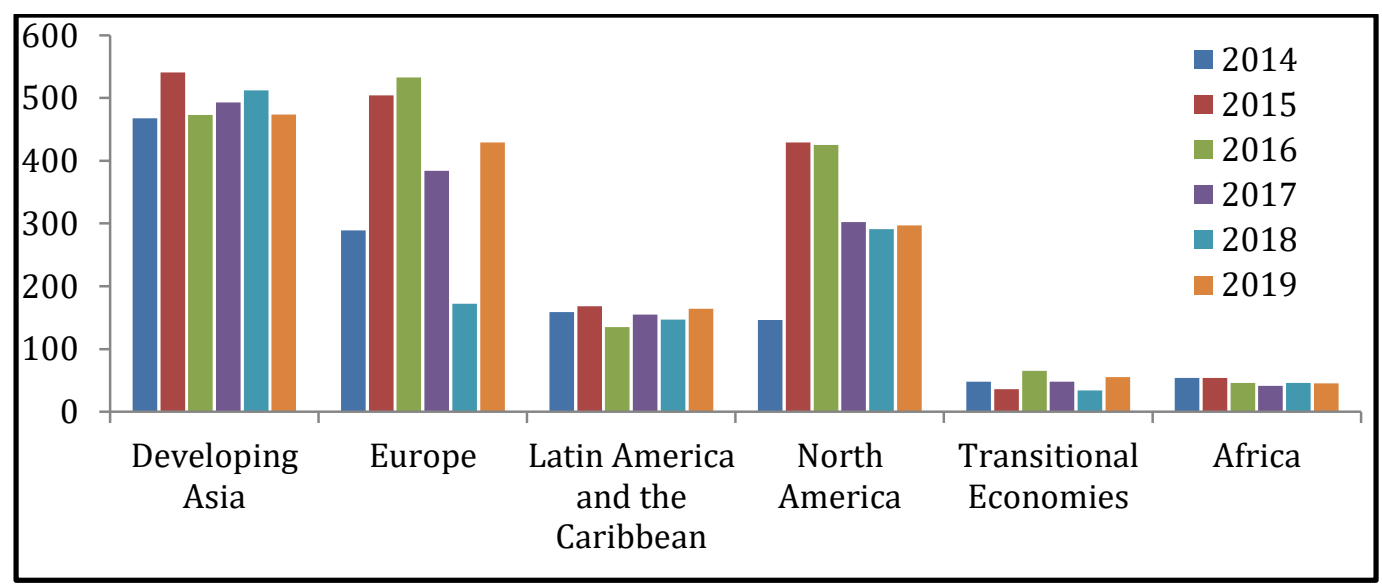

Data Source: World Investment Reports of different years

Table No. 1: Summary Statistics of the Study Variables

\begin{tabular}{|c|c|c|c|c|c|}
\hline $\begin{array}{c}\text { Variable } \\
\text { Name }\end{array}$ & $\begin{array}{c}\text { Total } \\
\text { Observations }\end{array}$ & Mean Value & Std. Dev & $\begin{array}{c}\text { Minimum } \\
\text { Value }\end{array}$ & $\begin{array}{c}\text { Maximum } \\
\text { Value }\end{array}$ \\
\hline CAB & 41 & 226378.3 & 256154.1 & -61567.95 & 754812.4 \\
\hline FDI_Inflows & 41 & 197718.4 & 186727.1 & 573.1891 & 514307.9 \\
\hline GDP & 41 & 9079930 & 8792044 & 1395579 & $2.76 \mathrm{e}+07$ \\
\hline TO & 41 & 6190605 & 5727260 & 709642.1 & $1.68 \mathrm{e}+07$ \\
\hline
\end{tabular}

Data Source and unit of measure: UNCTAD, million US \$.

Table 01 shows the summary statistics of the variables used in the present study. All the variables have equal number of observation and having a total 41 number of observations. Values of standard deviation column show that all the variables have large variations. The values of current account balance ranges from negative to positive value. Negative value indicates current account deficit. The min value belongs to 1991 indicating highest current account deficit in developing Asia in 1991. FDI inflows have lowest value 573.1891 and this is in year 1980. After 1980 developing Asia has increasing volume of FDI inflows with slight variations.

Table No. 2: Correlation Matrix of the Study Variables

\begin{tabular}{|l|l|l|l|l|}
\hline & CAB & FDI_Inflows & GDP & TO \\
\hline CAB & 1.000 & & & \\
\hline FDI_Inflows & 0.8803 & 1.000 & & \\
\hline GDP & 0.7677 & 0.9638 & 1.000 & \\
\hline TO & 0.8582 & 0.9865 & 0.9827 & 1.000 \\
\hline
\end{tabular}

Table 02 reported the results of correlation among study variables. All the variables have positive and substantial correlation with each other.

\section{RESULTS AND DISCUSSION}

To go for appropriate estimation technique, prior to estimations the unit root test was employed to identify the order of integration and for the selection of suitable estimation technique. To examine stationarity is also important to prevent the presence of false estimation results. Augmented Dickey Fuller (ADF) unit root test is used to observe the stationarity the variables. The results of ADF test are presented in table 03 . 
Table No. 3: Augmented Dickey Fuller (Unit Root) Test

\begin{tabular}{|c|c|c|c|c|}
\hline \multirow{2}{*}{} & \multicolumn{2}{|c|}{ Level } & \multicolumn{2}{c|}{ First difference } \\
& \multirow{2}{*}{ Intercept } & Trend and Intercept & Intercept & Trend and Intercept \\
\hline \multirow{2}{*}{ Variable } & \multicolumn{2}{|c|}{ Test Statistics } & \multicolumn{2}{c|}{ Test Statistics } \\
& \multicolumn{2}{|c|}{ (Prob) } & -5.616204 & -5.499501 \\
\multirow{2}{*}{ ICAB_Deficit } & 0.399828 & -2.547933 & $0.0000^{* *}$ & $0.0004^{* *}$ \\
\hline \multirow{2}{*}{ LFDI } & 0.9801 & 0.3049 & 5.107099 & -5.296617 \\
& $-2.352825(06)$ & $-3.649582(06)$ & $0.0002^{* *}$ & $0.0007^{* *}$ \\
\hline \multirow{2}{*}{ LGDP } & $(0.1636)$ & $(0.0456)^{*}$ & -3.573115 & -3.752169 \\
& 1.491418 & -1.918923 & $0.0118^{*}$ & $0.0321^{*}$ \\
\hline \multirow{2}{*}{ LTO } & 0.9990 & 0.6235 & -4.773344 & 4.752714 \\
& 0.392113 & -3.123742 & $0.0005^{* *}$ & $0.0029^{* *}$ \\
\hline
\end{tabular}

*Indicates the level of significance, $*$ is for $5 \%$ and $* *$ are for $1 \%$ level of significance.

The results of ADF test show that all variables are stationary at first difference; however, log of FDI is stationary at level. ARDL approach to cointegration is used for long run analysis since mixed order of integration is found in the study variables. In ARDL model at first, we have to determine the optimal lag length by using VAR lag length selection criterion. After determining the optimal lag length next step is to perform the bound testing to compute the value of F-statistics. The calculated value of $F$ through Wald test will demonstrate either cointegration exists among study variables or not. If we found the cointegration amongst study variables then at next step long and short run coefficients will be estimated.

Table No. 4: VAR Lag Order Selection Criterion

\begin{tabular}{lllll}
\hline Lag & AIC & SC & HQ \\
\hline 0 & -7.874970 & -7.695398 & -7.813731 \\
\hline 1 & $-16.02515^{*}$ & $-15.12729^{*}$ & $-15.71895^{*}$ \\
\hline 2 & -15.92434 & -14.30819 & -15.37319 \\
\hline
\end{tabular}

*indicates optimal lag length

AIC: Akaike information criterion

SC: Schwarz information criterion

HQ: Hannan-Quinn information criterion

All the criteria using in VAR lag selection procedure indicating that one is the optimal lag length for the model. Using one lag length now F- statistics would be calculated using Wald test (F-Statistics) and by imposing restriction on equations.

$$
\begin{aligned}
& \Delta C A B=\alpha_{0}+\alpha_{1 i} \sum_{j=i}^{k} \Delta C A B_{t-j}+\alpha_{2 i} \sum_{j=0}^{k} \Delta F D I_{t-j}+\alpha_{3 i} \sum_{j=0}^{k} \Delta G D P_{t-j}+\alpha_{4 i} \sum_{j=0}^{k} \Delta T O_{t-j}+ \\
& \alpha_{5} C A B_{t-1}+\alpha_{6} F D I_{t-1}+\alpha_{7} G D P_{t-1}+\alpha_{8} T O_{t-1}+\varepsilon_{t}
\end{aligned}
$$

Where the notation $\Delta$ indicates change in variables and all variables are previously defined.

The bounds test is mainly based on the joint $F$-statistic whose asymptotic distribution is non-standard under the null hypothesis of no cointegration. The null and alternative hypotheses for cointegration test on the basis of equation 3 is given as:

H0: $\alpha_{5}=\alpha_{6}=\alpha_{7}=\alpha_{8}=$ (No evidence of long-run relationships) 
H1: $\alpha_{5}=\alpha_{6}=\alpha_{7}=\alpha_{8} \neq 0 \quad$ (long-run relationships exits among study variables)

Results of the Bound test of cointegration are presented in Table 05. Results of bound test show that the calculated F-statistics of model (LCAB, LFDI, LGDP, LTO) is greater than upper limits of tabulated F-values at 5 percent level of significance, which provides evidence for the existence of cointegration among study variables. Similar results are reported by Jaffri et al. (2012). They confirmed the same results using time series data for Pakistan economy. Another study by Ali and Shaheen (2013) also endorsed the same kind of results using quarterly data for Pakistan economy.

Table No. 5: Results of the Bound Test for the Model

\begin{tabular}{|c|c|c|}
\hline \multicolumn{3}{|c|}{ Bound Test for Cointegration } \\
\hline F-Statistics & \multicolumn{2}{|c|}{$\mathbf{4 . 7 4 9 8 4 7}$} \\
\hline $\begin{array}{l}\text { Selected Lag Length } \\
\text { (Criteria) }\end{array}$ & \multicolumn{2}{|c|}{ (S1 } \\
\hline \multicolumn{2}{|c|}{ Pesaran et al. (2001) } \\
\hline Level of significance & Lower Critical Bound Value & Upper Critical Bound Value \\
\hline $10 \%$ & 2.72 & 3.77 \\
\hline $5 \%$ & 3.23 & 4.35 \\
\hline $2.5 \%$ & 3.69 & 4.89 \\
\hline $1 \%$ & 4.29 & 5.61 \\
\hline
\end{tabular}

Cointegration is found among study variables now the next task is to estimate the short-run and long run relationships using Ordinary Least Square (OLS) method under ARDL approach. To estimate the long run relationship following equations can be specified for the model.

$C A B=\alpha_{0}+\alpha_{1} \sum_{j=1}^{k} C A B_{t-j}+\alpha_{2} \sum_{j=0}^{k} F D I_{t-j}+\alpha_{2} \sum_{j=0}^{k} G D P_{t-j}+\alpha_{2} \sum_{j=0}^{k} T O_{t-j}+\varepsilon_{i t}$

After testing the long run cointegration among the study variable then the vector error correction model is tested to check the short run relationship among the study variables. In short run analysis lagged value of error term [ECM $\left.M_{t-1}\right]$ shows the speed of adjustment if any disequilibrium occurs in long run normal path. To test the VECM following equation would be used.

$\triangle C A B=$

$\beta_{0}+\beta_{1 i} \sum_{j=i}^{k} \Delta C A B_{t-j}+\beta_{2 i} \sum_{j=0}^{k} \Delta F D I_{t-j}+\beta_{3 i} \sum_{j=0}^{k} \Delta G D P_{t-j}+\beta_{4 i} \sum_{j=0}^{k} \Delta T O_{t-j}+\beta_{5} E C M_{t-1}+$ $\mu_{i t}$

Results of the long run and short run analysis are reported in Table 06. The findings show that FDI has positive impact on $\mathrm{CAB}$ deficit, and it is significant at 10 percent significance level. The coefficient of FDI show that a one percent increase in FDI inflows lead to $\mathbf{0 . 6 7 4 6 6 8}$ percent increase in current account deficit in the long run. This outcome indicates that in case of developing Asia more inward FDI can cause CAB deficit. The results are similar to the results of Jaffri et al. (2012) and results of Ali and Shaheen (2013) as these studies also proved inward FDI can have negative impact on $\mathrm{CAB}$ of host economy in case of Pakistan. Results are also similar to the results of Seabra and Flach (2005), Strauss (2015) and Strauss (2016) as they proved FDI can worsen CAB position by enlarging the profit remittances. On the other side results are in contrast with the results of Ali et al. (2019), as they proved that inward FDI has negative impact on current account deficit for the East Asian economies.

Table No. 6: Long Run and Short Run Relationship among Study Variables

\begin{tabular}{|l|l|l|l|}
\hline \multirow{4}{*}{ Variable } & \multicolumn{2}{l|}{ Dependent Variable: LCAB_Deficit } \\
\cline { 2 - 4 } & \multicolumn{2}{|l|}{ Long Run Equation } \\
\cline { 2 - 4 } & Coefficient & T-statistic & Prob \\
\hline LFDI & 0.674668 & 1.743122 & 0.0916 \\
\hline
\end{tabular}




\begin{tabular}{|l|l|l|l|}
\hline LGDP & -1.180915 & -2.452457 & 0.0202 \\
\hline LTO & 1.416620 & 3.050378 & 0.0047 \\
\hline C & -4.637716 & -7.952037 & 0.0000 \\
\hline \multicolumn{4}{|c|}{ Short Run Equation } \\
\hline D(FDI) & 0.256684 & 1.192382 & 0.2425 \\
\hline D(GDP) & -0.449290 & -2.481095 & 0.0189 \\
\hline D(TO) & 0.538966 & 4.564654 & 0.0001 \\
\hline ECM(-1) & -0.380459 & -2.657782 & 0.0125 \\
\hline Jarque-Bera Normality test & $\begin{array}{l}1.789411 \\
(0.408728)\end{array}$ & \\
\hline Breusch-Godfrey Serial Correlation LM Test & $\begin{array}{l}0.731910 \\
(0.4900)\end{array}$ \\
\hline Heteroskedasticity Test: ARCH & $\begin{array}{l}0.00038 \\
(0.9844)\end{array}$ \\
\hline
\end{tabular}

( ) shows p-values of F-statistics

Results also dissimilar to the results of Ali and Sadiq (2020) who proved that inward FDI can improve the current account balance position of the host economies in case of South Asian economies. Ehimare (2011) was explored positive impact of inward FDI on host country CAB in case of Nigeria. The later stated studies proved that inward FDI can improve the $\mathrm{CAB}$ position by reducing the deficit in $\mathrm{CAB}$.

Results also indicated negative impact of GDP on current account deficit indicating that increase in GDP can reduce the current account deficit. The possible channel for this positive impact of GDP on CAB position can as GDP increase, domestic output increases and it can increase the exports of the country. Increase in exports can increase the volume of net exports which can eventually improve the CAB position. The result is consistent with the result of Ali and Sadiq (2020) as they proved that increase in GDP can reduce the CAB deficit in enlarging the exports of host economy in case of south Asia. On the contrary negative coefficient of GDP is inconsistent with the findings of the Ali et al. (2019), since they proved that increase in GDP can enlarge the CAB deficit by increasing the imports of the host economy in case of East Asia.

The coefficient of trade openness is positive indicating inward FDI can increase CAB deficit. The implication of this negative sign can be justified as more openness means more import of intermediate goods by FDI companies. FDI companies sometimes enlarge the imports of host economy by importing raw material, intermediate inputs or/and capital goods which they are required but not available in host economy (Hossain, 2008). Another justification of this negative impact of trade openness on $\mathrm{CAB}$ is, more open developing economies normally import more and exports less, which can deteriorate the current account balance by contributing to trade deficit. The result is dissimilar to the result of Ali et al. (2019), as they proved that trade openness can improve CAB position in case of East Asian economies. Results are also in contrast with the results of Ali and Sadiq (2020) since theylproved that FDI has positive impact on both on exports and imports. However, the elasticity of exports to FDI is larger than the elasticity of imports to FDI. They proved that trade openness can reduce $\mathrm{CAB}$ deficit by enhancing the volume of exports.

The short run results of the model are almost like the long run results. The coefficient of lagged value of error term is $\mathbf{- 0 . 3 8}$ with expected negative sign. The value of ECM coefficient is less than one with negative sign and it is significant. The significant error term indicates that if there is any deviation from the long run equilibrium path then the error will be eliminated almost $\mathbf{3 8 \%}$ every year and it will converge to long run equilibrium. Diagnostic tests are applied to check the stability of the model. Results of diagnostic tests revealed that data is normally distributed having constant variance and no serial correlation in error terms is present. 


\section{CONCLUSION AND POLICY RECOMMENDATIONS}

Most of the existing literatures on FDI highlight its positive impact on the recipient economy, by ignoring its negative implications on current account balance. This study was an effort to contribute the existing literature to fill the gap. As the present study highlighted the negative implication of the FDI inflows on the current account balance of recipient country in case of developing Asia. Time series data from 1980 to 2020 is used for the group of developing Asian economies. ARDL approach to cointegration is used for empirical analysis. Results found that FDI inflows have positive and statistically significant impact on current account deficit, indicating that inward FDI can deteriorate the $\mathrm{CAB}$ position of the host economy by enlarging the $\mathrm{CAB}$ deficit. Policy suggestion based on results is as developing Asia has \become the world's largest host of FDI (WIR, 2021), so this region should attract sector specific FDI. Initially country must build its confidence for foreign investors, as country becomes potential destination for inward FDI then this inflow of FDI should be sector specific. It should come only to produce tradable goods which can enhance the exports of the country, instead enlarging the imports of host economy. Moreover, this inflow can come for the development of local infrastructure where local investor may be reluctant to invest.

\section{REFERENCES}

Alguacil, M. T., \& Orts, V. (2003). Inward foreign direct investment and imports in Spain. International Economic Journal, 17(3), 19-38.

Ali, M., Ahmad, T. I., \& Sadiq, R. (2019). Empirical investigation of foreign direct investment and current account balance in East Asian economies. Pakistan Journal of Commerce and Social Sciences (PJCSS), 13(3), 779-795.

Ali, M. M., \& Sadiq, R. (2020). Foreign Direct Investment and Current Account Balance: The Case of South Asian Economies. Pakistan Journal of Social Sciences (PJSS), 40(4), 1577-1588.

Ali, M. M., \& Shaheen, S. (2013). Impact of Foreign Direct Investment Inflows on Income Outflows: A Case Study of Pakistan. Interdisciplinary Journal of Contemporary Research in Business, $5(1), 131-141$

Apergis, N., Katrakilidis, C. P., \& Tabakis, N. M. (2006). Dynamic linkages between FDI inflows and domestic investment: a panel cointegration approach. Atlantic Economic Journal, 34(4), 385394.

Bende-Nabende, A. (2002). Foreign direct investment determinants in Sub-Sahara Africa: A cointegration analysis. Economics Bulletin, 6(4), 1-19.

Bengoa, M., \& Sanchez-Robles, B. (2003). Foreign direct investment, economic freedom and growth: new evidence from Latin America. European journal of political economy, 19(3), 529-545.

Blomström, M., Kokko, A., \& Mucchielli, J. L. (2003). The economics of foreign direct investment incentives. In Foreign direct investment in the real and financial sector of industrial countries (pp. 37-60). Springer, Berlin, Heidelberg.

Carkovic, M., \& Levine, R. (2005). Does foreign direct investment accelerate economic growth. Does foreign direct investment promote development, 195.

Choe, J. I. (2003). Do foreign direct investment and gross domestic investment promote economic growth? Review of Development Economics, 7(1), 44-57.

Ehimare, O. A. (2011). Foreign direct investment and its effect on the Nigerian economy. Business Intelligence Journal, 4(2), 253-261.

Gorg, H., \& Strobl, E. (2001). Multinational companies and productivity spillovers: A metaanalysis. The Economic Journal, 111(475), F723-F739.

Hossain, M. A. (2008). Impact of foreign direct investment on Bangladesh's balance of payments: Some policy implications. Policy Note, 805.

Irandoust, J. E. M. (2001). On the causality between foreign direct investment and output: a comparative study. The International Trade Journal, 15(1), 1-26.

Jaffri, A. A., Asghar, N., Ali, M. M., \& Asjed, R., (2012). Foreign Direct Investment and Current Account Balance of Pakistan, Pakistan Economic and Social Review, 50 (2), 207-222.

Jansen, K. (1995). The macroeconomic effects of direct foreign investment: the case of Thailand. World Development, 23, 193-210. 
Kee, H. L. (2011). Local intermediate inputs, foreign direct investment and the performance of domestic firms: When firms share common local input suppliers. Policy Research Working Paper, World Bank.

Kumar, N. (2007). Regional economic integration, foreign direct investment and efficiency-seeking industrial restructuring in Asia: the case of India (No. 22110). East Asian Bureau of Economic Research.

Lehman, A. (2002). Foreign Direct Investment in Emerging Markets: Income, Repatriations and Financial Vulnerabilities. WP/02/47. International Monetary Fund: Policy Development and Review Department.

Lipsey, R. E. (2003). Foreign direct investment and the operations of multinational firms: Concepts, history, and data. Handbook of international trade, 285-319.

Lipsey, K. R., \& Chrystal, C. C. (2007). The impact of economic fundamentals on stock Markets in Africa. Development Southern Africa, 17(1), 23-51.

Makki, S. S., \& Somwaru, A. (2004). Impact of foreign direct investment and trade on economic growth: Evidence from developing countries. American journal of agricultural economics, 86 (3), 795-801.

Markusen, J. R. (1984). Multinationals, multi-plant economies, and the gains from trade. Journal of International Economics, 16(3-4), 205-226.

Markusen, J. R., \& Venables, A. J. (1999). Foreign direct investment as a catalyst for industrial development. European Economic Review, 43(2), 335-356.

Mencinger, J. (2008). The addiction with foregin direct investmnt and current account balance. International. ICER Working Papers 16-2008, Itlay: Center for Economic Research (ICER).

Meyer, K. E. (2003). FDI spillovers in emerging markets: A literature review and new perspectives. Copenhagen Business School (Mimographed.), 2.

Moran, T. H. (2011). Enhancing the contribution of FDI to development: a new agenda for the corporate social responsibility community, international labour and civil society, aid donors and multilateral financial institutions. Transnational Corporations, 20(1), 69-103.

Ozturk, I. (2007). Foreign direct investment-growth nexus: a review of the recent literature. International Journal of Applied Econometrics and Quantitative Studies, 4(2).

Pesaran, M. H., Shin, Y., \& Smith, R. J. (2001). Bounds testing approaches to the analysis of level relationships. Journal of applied econometrics, 16(3), 289-326.

Reenu, J. \& Sharma, A. K. (2015). Trends and determinants of foreign direct investment in India: a study of the post-liberalization period, South Asian Journal of Management, 22(3), 96-98.

Romer, P. M. (1986). Increasing returns and long-run growth. Journal of political economy, 94(5), 1002-1037.

Sala-i-Martin, X. X. (1996). Regional cohesion: evidence and theories of regional growth and convergence. European Economic Review, 40(6), 1325-1352.

Saini, N. \& Singhania, M. (2018), Determinants of FDI in developed and developing countries: A quantitative analysis using GMM, Journal of Economic Studies, 45(2), 348-382. https://doi.org/10.1108/JES-07-2016-0138

Schneider, F., \& Frey, B. S. (1985). Economic and political determinants of foreign direct investment. World development, 13(2), 161-175.

Siddiqui, D. A., \& Ahmad, M. H. (2012). The causal relationship between Foreign Direct Investment and Current Account: an empirical investigation for Pakistan economy. European Journal of Economics, Finance and Administrative Sciences ISSN, 1450-2275.

Seabra, F., \& L. Flach, (2005). Foreign Direct investment and Profit Outflows: A Causality Analysis for the Brazilian Economy. Economics Bulletin, 6(1), 1-15.

Toda, H. Y., \& T. Yamamoto, (1995). Statistical Inference in Vector Autoregressions with Possibly Integrated Processes, Journal of econometrics, 66.

United Nations Conference on Trade and Development (2021). World Investment Report (2002). New York and Geneva, United Nations

United Nations Conference on Trade and Development (2017). World Investment Report (2021). New York and Geneva, United Nations 
Ali, Bibi, \& Sadiq

Woodward, D., (2003). Financial Effect of Foreign Direct Investment in the Context of a Possible WTO Agreement on Investment, Presentation to NGO workshop on WTO negotiation on investment and new issues. Geneva, 18-19.

Zhang, K. H., \& Markusen, J. R. (1999). Vertical multinationals and host-country characteristics. Journal of Development Economics, 59(2), 233-252. 